EISSN: $2706-7947 \quad$ ISSN: 2077- 4613

DOI: 10.36632/mejas/2021.11.2.34

Journal homepage: www.curresweb.com

Pages: 421-434

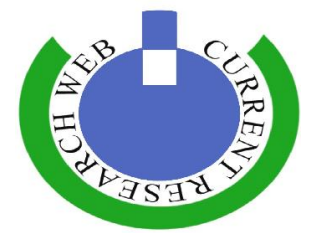

\title{
Increase of Biomass in Some Aquatic Plants Grow under Stress with Using Alternative Sources of Water and Use It as Contamination Indicators
}

\author{
Georgena Wahib Rizk Gabra
}

\author{
Botanical Gardens Department, Antoniades Garden, Horticultural Research Institute, Agriculture \\ Research Center, Alexandria, Egypt.
}

Received: 20 March $2021 \quad$ Accepted: 15 April Published: 20 April 2021

\begin{abstract}
Living organisms are distributed in ideal ecosystems in balanced proportions without prejudice to the existence of each other. The "Eutrophication" phenomena that means biomass aggravation increment of some aquatic plants occurs when increase the dietary excess by organic, inorganic nutrients and elements in water bodies because of sewage water 'wastewater' leakage into them. These aquatic macrophytes play a major role in conservation of the aquatic ecosystem or even aesthetically for some aquarium, ponds and artificial lakes as a part of the botanical gardens, water parks, fish farms and it may spread a lot in slowly flowing canals and rivers. The purpose of this study is to estimate the rates of increase in plants biomass produced under stress of using alternative water sources. Also, using these macrophytes as contamination biomarkers and in phyto-remediation process and what's for/on it and its impact in/on its presence in fresh water bodies. The most important of these macrophytes are Pistia stratiotes "water lettuce" as floating plant and Ceratophyllum demersum as submerged one. The experiment was carried out in open field of El- Harrery village, El Montaza, at the east of Alexandria, Egypt, during two successive summer seasons 2014 \& 2015 for 28, 34 days for each plant respectively. The plant samples were obtained from the National Center for Oceanography and Fisheries, ElAnfoushi, Quiet Bay, Alexandria, Egypt. The means of initial weights of plants were average at $47 \mathrm{~g}$ and 32g wet weight for each plant respectively. The treatments media were Tap Water as a control [TW] - Primary Treated Domestic Wastewater [PTW 15\%, 25\%] - Ground Well Water [GWW 15\%, 25\%] Mix $15 \%, 25 \%[\mathrm{TW}+\mathrm{PTW}+\mathrm{GWW}]$ from full volume $2.5 \mathrm{~L}$ of plastic Jars. The treatments were increased by the same concentration when the water evaporated. The results reached to highly significant differences between treatments in vegetative growth parameters, chemical constituents [total chlorophyll, N, P, K in plants tissues]and $\mathrm{Na}, \mathrm{Cd}$ and $\mathrm{Pb}$ in plants treated with $\mathrm{PTW} 25 \%$, sediment determination and water quality tests [color and turbidity] before and after the same treatment. The treatment of PTW 25\% proved its superiority in most vegetative growth parameters in both plants, but it caused that the fastest growing and the most degraded in water lettuce plant. Thus, it can be recommended that these plants can be released as pollution indicators and monitored in their environment and use this in phytoremediation process.
\end{abstract}

Keywords: Phytoremediation, Biomarkers, Eutrophication, Macrophytes, Ecosystem

\section{Introduction}

Living organisms are distributed in ideal ecosystems in balanced proportions without prejudice to the existence of each other. However, with the increase of dietary excess by organic, inorganic nutrients and elements then increase the biomass aggravation "eutrophication" of some aquatic plants in waterbodies (Smith et al., 1999; Ding et al., 2011). These macrophytes could affect the distribution of atmospheric oxygen in the water and then the preservation of aquatic organisms or even aesthetically for some ponds, artificial lakes as a part of the botanical garden, water parks, fish farms and slow flowing rivers. Thus, Water gardens can contain many varieties of types of ornamental plants, from

Corresponding Author: Georgena Wahib Rizk Gabra, Botanical Gardens Department, Antoniades Garden, Horticultural Research Institute, Agriculture Research Center, Alexandria, Egypt.

E-mail: georgena.rizk@yahoo.com 
submerged to emergent to free-floating with no contact with the substrate (Mahr, 2012). So, it was important to study some of these plant distributions and their worsening growth biomass and what's for/on it and its impact in/on its presence in fresh water bodies. Heavy metal contamination in aquatic habitats has been considered as one of the most serious problems threatening water sources, aquatic organisms and human health (Cheung et al., 1997; Sternberg and Dom, 2002; Hanafiah et al., 2018). Eutrophication and heavy metal problems lead us towards a greater problem, which is the leakage of sewage water 'wastewater' into fresh waterbodies, which is an important ecological problem that all poor and rich countries suffer from, which results in changing the bio-physiochemical properties of water and contaminating it with heavy metal (Ahmad et al., 2016 and Ali et al., 2020). Unfortunately, the advanced methods to removal of heavy metals is required high energetic costs and they have limited capacities or not sufficient to treat even very dilute solutions (Foroughi et al., 2011). Thus, Phytoremediation is one of the most eco- friendly, promising technology and low-cost methods of removing pollutants from aquatic ecosystem and sediment (Miretzky et al., 2004). This method is most effective for lowering high concentrations of hold excessive nutrients, organic and inorganic pollutants, and even more like dyes and crude oil (Volesky, 2003; Akapo et al., 2011 and Valipour et al., 2014). Plant species considered to be ideal phytoremediation agents have a high biomass, a good root system, and have easy fast-growing. These plants are classified according to their treatment of pollutants, so two or more techniques are used in order to be able to perform the function of phytoremediation. These mechanisms are phytoextraction [useful for mining purposes], phytoaccumulation [suitable for water purification], phytovolatilization [convert the pollutants to aromatic components and volatilize them into the atmosphere] and phytochelatins for soil amendments or etc (Mitsch and Jorgensen, 1989; Kushwaha et al., 2015; Fu and He, 2015 and Gabra, 2021). All of these plants can be used for medicinal, pharmaceutical and fodder purposes, so it can be used to improve the economic situation, especially in developing countries (Malathy and Stanley, 2015; Abu, 2017 and Shaltout et al., 2009). On the other hand, its unconditional release in nature, it causes many problems, such as hindering navigation, the spread of fish farm diseases, and the death of marine organisms. Also, it can clogs the river channels and causes alkalinity and salinity of the soil as one of the indirect negative effects (Gabra, 2021). So, the invasive aquatic macrophytes can escape into the surrounding environment and have a devastating effect on water quality and destroying their media and also the livelihoods of communities who depend on them (Yang et al., 2014; Thijs et al., 2017). Some countries are fighting these plants as a pest that must be eliminated, especially countries that suffer from water poverty under the pretext that these plants waste a large amount of water via evaporation. However, the environmental role of hydrophytes necessitates maintaining their presence due to their high ability to remove pollutants that cause poisoning of the water that is the source of life (Yadave et al., 2009). The high concentrations of heavy metals stimulate the biomass production of the macrophytes but for a limited period and not a concentration that lead to physiological death (Stebbing, 1981 and Sharma et al., 2012). Then a strange phenomenon occurs, which is called as "biphasic dose response" always characterized by J or invertedU shaped curve, also called Pistia-model (Eid et al., 2016). This phenomenon occurs naturally in the growth curve of aquatic plants. This phenomenon appears clearly in water lettuce plant, when the size of its rosettes becomes smaller and surrounding decreases until conditions improve for growth, so it regains its normal growth (Jia et al., 2013 andFarnese et al., 2014). Thus, these plants can be useful as biomarkers for toxicity. The characterization of biomarkers of toxicity is essential, since bio-indicators are, most of the time, more efficient than the physical and chemical parameters normally measured in the field (Barcelo et al., 1988).

Pistia stratiotes L., commonly called "water lettuce" because of its superficial resemblance to "lettuce" the green leafy vegetable. It is also occasionally called water cabbage or Nile cabbage, but is not edible. This species in the arum family (Araceae), it is the only one in the genus and likely originated in tropical or subtropical zone also, it is a strong competitor to other aquatic fresh water plants. This is an herbaceous perennial monocot with a rosette of overlapping, stem less leaves densely covered with fine hairs that prevent wetting of the actual leaf surface and trap air so the plant has increased buoyancy to float easily. The plant propagation vegetatively by 'stolons', each of which grows another rosette, with the daughter plants remaining connected to the mother plant. Under ideal conditions numerous stolons and new rosettes are formed, allowing the colony to grow quickly to cover the water surface. Although water lettuce can reproduce by seed, this is not a main means of propagation, especially when grown as an ornamental aquatic plant. It is adversely impact native flora and fauna - native submerged 
plants can be shaded out as the mat of leaves blocks light penetrating the water and fish may be killed from reduced oxygen in the water (Mahr, 2012 and Eid et al., 2016).

While, Ceratophyllum demersum L.," "Hornwort" plant is a dicotyledonous, submerged aquatic angiosperm belonging to the family Ceratophyllaceae. Sometimes the plant can branch but one for each node while, the branches are brittle and easily broken and they can grow apart with lack roots, or are present as capillaries. The flowers are unisexual; both staminate and pistillate on the same plant. The fruit is an achene, oval in shape, having one oblong seed 4-6 $\mathrm{mm}$ long, with the spineless lateral edges but having 1-2 basal spines (Abu, 2017). This plant grows in the aquarium for the beauty of vegetative growth, but in nature it can grow in slow-flowing freshwater-bodies such as lakes, canals and ponds with a high percentage of BOD. It has a high capacity for bio-sorption of iron, $\mathrm{Mn}$ and $\mathrm{Cu}$ from liquid wastes of factories (Ali and Soltan, 1999 and Ali et al., 1999).

Galal and Farahat 2015 founded that $P$. stratiotes has been shown to have great potential for the management of water quality, due to its capacity for the accumulation of heavy metals from wastewater. While, Eid, 2017 concluded that the Pistia-model can be used as a predictive tool for assessing the potential growth of $P$. stratiotes. It might be useful for practical applications, such as the management of irrigation and drainage canals, and to derive management recommendations for $P$. stratiotes control in regions where the species is considered invasive by assessing the critical growth stages of this plant. Also, Lu et al. (2010) investigated that water lettuce has a great potential for removing $\mathrm{N}$ and $\mathrm{P}$, reducing water suspended solids and turbidity from storm-waters, and improving water quality. Also number of leaves, plant weights, roots lengths and its numbers decreased with the increase of days affected by many factors like water salinity and physiological limitations of the plant. Brix, (1997) recommended that for efficient water purification, grown-up biomass of aquatic macrophytes must be removed from water bodies to keep an optimum plant density. If not harvested, the vast majority of the nutrients that have been incorporated into the plant tissue will be returned to the water by decomposition processes. Victor et al. (2016) studied that the phytoremediation with water lettuce plant were decreased the metal contents in treated wastewaters upto $3.51-93.51 \%$ after 15 days, and reduced $58.87 \%$ of ammonium content, $50.04 \%$ of PO4, $82.45 \%$ of COD and $84.91 \%$ of BOD. Kumar et al. (2019) showed that the highest removal of metals such as $\mathrm{Cu} \%, \mathrm{Fe} \%$ and $\mathrm{Hg} \%$ were observed in $5 \mathrm{mg} / 1$ treatment. The fresh biomass of water lettuce, chlorophyll content, and kinetic growth rate and plant root size were maximized in $5 \mathrm{mg} / \mathrm{l}$ treatment. Sidek et al. (2018) note that after 28 days, the physical observation shows that the water hyacinth was healthier than the water lettuces. Furthermore, water lettuce $(P$. stratiotes) was the most effective plant in removing Iron $(96.0 \%)$ and the turbidity $(50.0 \%)$ of the mining lake. In addition, Ali et al. (2020) experimented that the successful phytoremediation to remove the pollutants from wastewater and ground water with 3 species of aquatic macrophytes such as water hyacinth (Eichhornia crassipes), water lettuce (Pistia stratiotes) and duck weed (Lemna minor) they founded that the aquatic plants were prominent metal accumulator plants for the remediation of heavymetal polluted water.

In the same field, Foroughi et al. (2010) experimented that the phytoremediation "biosorption" with $C$. demersum on raw municipal wastewater (RMW) and treated municipal wastewater (TMW) for 18 days. The results showed that the COD of (RMW) and (TMW) were decreased from 664 to 152.75 $\mathrm{mg} / \mathrm{l}$ and 260 to $64.5 \mathrm{mg} / \mathrm{l}$, respectively. Also, the amount of ammonium decreased from 135 to $15 \mathrm{meq} / \mathrm{l}$ and 90 to $10 \mathrm{meq} / 1$, respectively. The amount of nitrate in RMW and TMW had a similar decreased from 60 to $30 \mathrm{meq} / \mathrm{l}$ as well as 4.48 to $0.53 \mathrm{meq} / \mathrm{l}$, respectively and the amount of phosphorous in RMW and TMW declined from 13.68 to $1.15 \mathrm{meq} / \mathrm{l}$ and 4.48 to $0.53 \mathrm{meq} / \mathrm{l}$, respectively. So, the significant amounts of these macro elements were removed by $C$. demersum. And the $\mathrm{EC}$ of treated municipal wastewater was reduced from $(1.34$ to $0.95 \mathrm{dS} / \mathrm{m}$ ) and of raw municipal wastewater (from 2.68 to 2.12 $\mathrm{dS} / \mathrm{m}$ ) also, due to biosorption with $C$. demersum. Meanwhile, Patel and Kanungo, (2010) studied that the net primary productivity of Ceratophyllum demersum L. in domestic wastewater culture for a week interval was determinate by increase of biomass to $1.58 \mathrm{~m}^{2} / \mathrm{day}$. But an increase in value of $\mathrm{pH}, \mathrm{DO}$ and Percentage oxygen saturation value while, the other parameters viz. Turbidity, Salinity, EC, TDS, Alkalinity, Free carbon dioxide, Chloride, COD, Total hardness, Calcium hardness, $\mathrm{Ca}, \mathrm{Mg}, \mathrm{N}$ and Phosphorus as Phosphate recorded a significant decrease in values due to absorption of nutrients during phytoremediation. So, the quantitative reduction of nutrients in domestic wastewater and increase in biomass productivity value had suggested Ceratophyllum demersum L. as an ecologically efficient aquatic plant for phytoremediation of nutrients from domestic waste water. Al-Ubaidy and Rasheed, 
(2015) investigated that the ability of $C$. demersum to reduce or eliminate the harmful and toxic effect, which resulting from two concentrations of cadmium chloride $(3.714,4.952 \mathrm{mg} / \mathrm{l})$. The results showed that cadmium accumulated rapidly in the plant and increased dramatically with time, thus the highest level of cadmium was observed at day nine. $C$. demersum showed high ability to remove cadmium and was at the $9^{\text {th }}$ day of the experiment and that was $(1.53,1.089 \mathrm{mg} / \mathrm{l})$ when exposed to $3.714,4.952 \mathrm{mg}$ $/ 1$ of cadmium respectively. The current study proved strongly the ability of $C$. demersum to eradicate the cadmium in ecosystem. Also, Ghobrial, (2000) studied that the phytoremediation of $C$. demersum on 2:5 wastewater concentration within 9 days to realizing maximum uptake and accumulation of $\mathrm{Cd}$ and $\mathrm{Cu}$. She founded that these contents were increased to 2.9 and 3.9 folds higher than the control plants. And $\mathrm{Zn}$ was increase of 2.2-75.5 times the initial content in the plant. The accumulation of $\mathrm{Fe}$ was greatest in plants grown on 4:5 wastewater dilutions in 7 days treatment. While, Mn ion increase slightly and $\mathrm{K}, \mathrm{Na}$ ions were decrease at the beginning of treatment followed by considerable increase in $\mathrm{K}$ content. The growth rate was excess $4 \mathrm{~g} /$ day in fresh weight even at the low waste dilution. Thus C. demersum may prove useful in the detoxification of domestic wastewater and has a capacity to accumulation heavy metals within its tissues.

So, the purpose of this study aimed to determine the increase of biomass of two types of freshwater aquatic hydrophytes such as 'Water lettuce' Pistia stratiotes L. as a emergent or free-floating plant and Ceratophyllum demersum L. as a submerged one and use their growth rate as a biomarker or pollution indicator especially, they have a proven ability to survive and tolerant high concentrations of pollutants. Meanwhile, their large biomass is an indication of the timing of its accumulation of the largest amount of pollutants, when it grows in several concentrations of primary treated wastewater and groundwater wells.

\section{Materials and Methods}

The experiment was carried out in open field of El- Harrery village, El Montaza, at the east of Alexandria, Egypt, during two successive summer seasons 2014 and 2015. The purpose of this study is to estimate the rates of increase in biomass production of Pistia stratiotes L. and Ceratophyllum demersum L. under stress of using two types of alternative water sources such as primary treated domestic wastewater and underground well water. Also, how can using these plants in phytoremediation process and contamination biomarkers.

The plant samples of Pistia stratiotes L. and Ceratophyllum demersum L. were obtained from the National Center for Oceanography and Fisheries, El- Anfoushi, Quiet Bay, Alexandria, Egypt. The means of initial weights of plants were average at $47 \mathrm{~g}$ and $32 \mathrm{~g}$ for each plant respectively. All samples were washed with tap water to be cleaned of any soil or sediment particles attached to the plant surfaces. Thus, they were cultivated at 15 Jun lasted until 28, 34 days for each plant respectively in both seasons.

The treatments media were Tap Water as a control [TW] - Primary Treated Domestic Wastewater [PTW 15\%, 25\%] from " Domestic Wastewater Treatment Station, Smoha-Alex., Egypt " Underground Well Water [GWW 15\%, 25\%] "from Vadinas nursery at $24 \mathrm{~km}$, Alexandria-Matrowh high way, the Northwest Coast of Egypt" - and Mix 15\%, 25\% [TW+PTW+GWW] from full volume $2.5 \mathrm{~L}$ of transparent plastic Jars. The chemical and physical analyses of three kinds of water before treatments with plants were appeared in Table (1). The treatments were increased by the same concentration when the water evaporated. All of growth criteria, and chemical constituents for each plant and sediment wet weight were determined at the major biomass stage at $21^{\text {st }}$ day and $28^{\text {th }}$ day from cultivated $P$. stratiotes L. and C. demersum L., respectively. After this stage the treatments were continued to determine the decrease of biomass rate (negative values) and the frayed tissues was excesses in both plant. But the water tests were determined in the highly concentration treatment of wastewater [PTW 25\%], before and after the majority of plants biomass stage.

\section{A- Vegetative growth criteria of Pistia stratiotes L. were:}

Leaves number, plant fresh weight $(\mathrm{g})$, the growth rate $(\mathrm{g} /$ day), shoots dry weight $(\mathrm{g})$, leaf thickness $(\mathrm{cm})$, leaf width $(\mathrm{cm})$, rosettes diameter $(\mathrm{cm})$, root length $(\mathrm{cm})$, roots dry weight $(\mathrm{g})$, and sediment wet weight $(\mathrm{g})$, then, plant wet weight at $28^{\text {th }}$ day $(\mathrm{g})$, the decrease of biomass rate $(\mathrm{g} /$ day), the decrease of rosettes diameter $(\mathrm{cm})$ and wet weight of frayed tissues $(\mathrm{g})$. 
The equations of the growth rate and the decrease of biomass rate were:

$$
\text { Growth rate }(g / \text { day })=[\text { last fresh weight }- \text { initial fresh weight }] \div \text { days number }
$$

Table 1: The chemical and physical analysis of three kinds of water treatments before experiment [22 ${ }^{\circ} \mathrm{C}$ of water] as follow:

\begin{tabular}{|c|c|c|c|c|}
\hline $\begin{array}{c}\text { Chemical and physical } \\
\text { analysis of three types of } \\
\text { water }\end{array}$ & Units & $\begin{array}{l}\text { Primary treated } \\
\text { wastewater } \\
{[\text { PTW] }}\end{array}$ & $\begin{array}{c}\text { Underground well } \\
\text { water } \\
\text { [GWW] }\end{array}$ & $\begin{array}{c}\text { Tap water } \\
{[\mathrm{TW}]}\end{array}$ \\
\hline $\mathrm{pH}$ & & 8.3 & 8 & 7.3 \\
\hline Ec & $\mathrm{dS} / \mathbf{m}$ & 16.12 & 7.93 & 1.63 \\
\hline TDS & $\mathrm{mg} / \mathrm{l}$ & 7459.2 & 3148.0 & 137.7 \\
\hline DO & $\mathrm{mg} / \mathbf{l}$ & 20.06 & 9.21 & 0.98 \\
\hline SO4 & ppm & 89.25 & 38.44 & 6.05 \\
\hline NO3 & $\mathrm{mg} / \mathbf{l}$ & 102.3 & 0.528 & 0.116 \\
\hline NH4 & $\mathrm{mg} / \mathrm{l}$ & 116.7 & 6.67 & 0.232 \\
\hline $\mathrm{HCO3}$ & ppm & 60.75 & 8.01 & 0.532 \\
\hline $\mathbf{F e}$ & $\mathrm{mg} / \mathrm{l}$ & 5.68 & 2.25 & 3.10 \\
\hline $\mathrm{Na}$ & $\mathrm{mg} / \mathrm{l}$ & 175.90 & 58.4 & 18.5 \\
\hline $\mathbf{K}$ & $\mathbf{m g} / \mathbf{l}$ & 41.4 & 30.32 & 10.2 \\
\hline $\mathbf{C a}$ & $\mathbf{m g} / \mathbf{l}$ & 59.67 & 25 & 5.95 \\
\hline Mg & $\mathbf{m g} / \mathbf{l}$ & 63 & 14.4 & 1.56 \\
\hline Mn & $\mathrm{mg} / \mathbf{l}$ & 0.421 & 0.187 & 0.121 \\
\hline $\mathbf{Z n}$ & $\mathbf{m g} / \mathbf{l}$ & 2.604 & 0.466 & 0.29 \\
\hline Cd & $\mathrm{meq} / \mathrm{l}$ & 6.43 & 3.53 & 0.507 \\
\hline $\mathbf{P b}$ & $\mathrm{meq} / \mathrm{l}$ & 1.109 & 0.601 & 0.439 \\
\hline Total P & $\mathrm{mg} / \mathrm{l}$ & 21.2 & 8.14 & 1.72 \\
\hline Turbidity & NTU & 25.5 & 12.52 & 5.8 \\
\hline Color & $\mathrm{Pt} / \mathrm{co}$ & $\begin{array}{c}54 \\
\text { gray }\end{array}$ & $\begin{array}{c}18 \\
\text { vellowish }\end{array}$ & $\begin{array}{c}12 \\
\text { bright }\end{array}$ \\
\hline
\end{tabular}

\section{B- Vegetative growth criteria of Ceratophyllum demersum L.:}

Shoots fresh weight $(\mathrm{g})$, the growth rate $(\mathrm{g} /$ day) by the same equation, shoots dry weight $(\mathrm{g})$, sediment wet weight $(\mathrm{g})$, plant wet weight at $34^{\text {th }}$ day $(\mathrm{g})$, the decrease of biomass rate $(\mathrm{g} /$ day) and wet weight of frayed tissues $(\mathrm{g})$.

\section{C- Chemical constituents:}

Total chlorophyll $\mathrm{mg} / \mathrm{g}$ fresh weight in the leaves was determined by direct spectrophotometer method according to (Moran, 1982).

N\% was determined according to (Evenhuis and Deward, 1980), P\% was determined according to (Trouge and Meyer, 1939) and K \% was determined according to (Brown and Lilliland, 1946) in the dried plant tissues from $1 / 2$ numbers of replicate plants.

$\mathrm{Na}, \mathrm{Cd}, \mathrm{Pb}$ in plant shoot of $25 \%$ PTW at $21^{\text {st }}$ day, $28^{\text {th }}$ and $28^{\text {th }}$ day, $34^{\text {th }}$ day for both plant respectively 4 - water quality tests [color and turbidity] before /after major biomass in treatment of $25 \%$ PTW.

The experimental design was CRD [complete randomized design] as 7 treatments were replicated three times each replicate contains 6 Jars. The experiment consists of 126 plants [one plant /jar], in both seasons for each plant. Also, Means of data of the different treatments were compared using Duncan's Multiple Range test according to (Snedecor and Cochran, 1974).

\section{Results and Discussion}

Increase of biomass of Pistis stratuotus L. and Ceratophyllum demersum L. grow under stress with using alternative sources of water [primary treated domestic wastewater and underground well water] and use its criteria of biomass productivity as contamination indicators. 


\section{1- The vegetative growth criteria of Pistis stratuotus L. 'Water lettuce' :}

The estimated measurements shown in Table $(2,3)$ for both two successive summer seasons 2014 and 2015 are [leaves number, plant fresh weight $(\mathrm{g})$, the growth rate (g/day), shoots dry weight ( $\mathrm{g}$ ), leaf thickness $(\mathrm{cm})$, leaf width $(\mathrm{cm})$, rosettes diameter $(\mathrm{cm})$, root length $(\mathrm{cm})$, roots dry weight $(\mathrm{g})$, and sediment wet weight (g)] as in Table (2) at the $21^{\text {st }}$ day or the majority biomass stage of water lettuce. And parameters of plant wet weight at $28^{\text {th }}$ day $(\mathrm{g})$, the decrease of biomass rate $(\mathrm{g} /$ day), the decrease of rosettes diameter $(\mathrm{cm})$ and wet weight of frayed tissues $(\mathrm{g})$ in Table (3) at the end of experiment.

All of these parameters were agreed together on the superiority of the most concentrated treatment of pollutants was $(25 \% \mathrm{PTW})$, which gave the highly significant values for all biomass measurements in both seasons followed by $15 \% \mathrm{PWT}$ in some cases such a leaves number, plant fresh weight, the growth rate and shoots dry weight in both seasons and sediment wet weight $2^{\text {nd }}$ season. While there were no significant differences between the treatments of 25\% PTW and 25\% Mix in the parameters of leaves number in $1^{\text {st }}$ season and leaf thickness and root length in second season.

This is a grater indicator to the plant efficiency to assimilate the nutrient mineral elements in its tissues and convert them from an overly toxic polluted state to organic biomass. Also, the significant increase in the sediment weight resulting from the treatment of $25 \% \mathrm{PTW}$ explains that the root may have excreted some substances or adsorbed particles suspended in the water and turned them to sediment, which indicates the extent of the ability of plant to reduce the turbidity of the aqueous media. All of these results indicate that the treatments that contain a higher concentration of pollutants as a result of the addition of sewage water 'primary treated wastewater' led to an increase in the organic mass of Pistis stratuotus L. plant during the first $21^{\text {st }}$ days of the experiment. Where these results are consistent with the findings of Lu et al., (2010); Jia et al., (2013) and Farnese et al., (2014); Victor et al., (2016); Eid et al., (2016); Eid, (2017) and Kumar et al., (2019).

On the other hand, the growth criteria in Table (3) indicated to the limited decrease of plant's organic mass with a long time which shown in parameters of [plant wet weight at $28^{\text {th }}$ day, the decrease of biomass rate, the decrease of rosettes diameter and wet weight of frayed tissues]. The significant values of decrease of plant wet weight in parallel with the decrease of biomass rate of plants and the faster with time at the day of $28^{\text {th }}$ were resulting from the treatment of $25 \%$ PTW followed by $15 \%$ PTW in some cases, rather it indicates that the more concentrated treatments of pollutants after a short time, became the least abundant of nutrients and lack of availability of more these elements as a result of the high rate of accumulation in plant tissues. So the least of metal was led to the rapid destruction of plant tissues and the excess of the frayed tissues despite this, the plants were still alive but had lost layers of lower leaves close to the surface of the water.

Also, the results show that the rate of decrease of biomass [negative values] was faster than the rate of positive growth rate, which is an important indicator that confirms that there is a maximum growth limit at a certain point in time which the accumulation of pollutant elements is the maximum in the plant. At this time if the plants in not removed from aquatic system, its tissues will degrade and the elements will be liberated, leaving again to pollute the aquatic ecosystem and this is known as Pistiamodel according to Eid et al. (2016) or called as "biphasic dose response" according to Jia et al., (2013); Farnese et al., (2014) and Kumar et al., (2019).

\section{2- Vegetative growth criteria of Ceratophyllum demersum L.:}

It is clear from data in Table (4) that using alternative sources of two types of water such as primary treated domestic wastewater and underground well water and mix of them had a significant effect on all criteria of vegetative growth like shoots fresh weight $(\mathrm{g})$, the growth rate $(\mathrm{g} /$ day), shoots dry weight $(\mathrm{g})$, sediment wet weight $(\mathrm{g})$. And the parameters of Plant wet weight at $34^{\text {th }}$ day $(\mathrm{g})$, the decrease of biomass rate (g/day) and wet weight of frayed tissues $(\mathrm{g})$ at the end of experiment. The results were appeared that all plants treated with $25 \% \mathrm{PTW}$ were the highest significant in the estimated values in most cases. While there were no the significant different values between the treatments of $25 \% \mathrm{PTW}$, $15 \% \mathrm{PTW}$ and $25 \%$ Mix in parameter of shoots fresh weight $(\mathrm{g})$ and the growth rate in both seasons. However the control treatment gave the highly values in the shoots dry weight in both seasons and was the lowest in the sediment formation and frayed tissues. Also, the parameter of plant wet weight at $34^{\text {th }}$ day with the other one of decrease of biomass rate note to the same direction results of Pistis stratuotus $L$., where the rate of reduce in the biomass of the plant was faster than the rate of growth. However, the 
Table 2: The vegetative growth criteria of Pistis stratuotus L. 'Water lettuce' grows under stress under stress with using alternative sources of water[ primary treated domestic wastewater and underground well water] during two summer seasons 2014 and 2015.

\begin{tabular}{|c|c|c|c|c|c|c|c|c|c|c|}
\hline Treatment & $\begin{array}{l}\text { Leaves } \\
\text { number }\end{array}$ & $\begin{array}{c}\text { plants fresh } \\
\text { weight } \\
\text { (g) }\end{array}$ & $\begin{array}{l}\text { The } \\
\text { growth } \\
\text { rate } \\
\text { (g/day) }\end{array}$ & $\begin{array}{l}\text { Shoots dry } \\
\text { weight } \\
\text { (g) }\end{array}$ & $\begin{array}{l}\text { Leaf thickness } \\
\text { (cm) }\end{array}$ & $\begin{array}{c}\text { Leaf } \\
\text { width } \\
(\mathrm{cm})\end{array}$ & $\begin{array}{l}\text { Rosettes } \\
\text { diameter } \\
(\mathbf{c m})\end{array}$ & $\begin{array}{c}\text { Root } \\
\text { length } \\
(\mathrm{cm})\end{array}$ & $\begin{array}{l}\text { Roots dry } \\
\text { weight } \\
\text { (g) }\end{array}$ & $\begin{array}{c}\text { Sedimentw. } \\
\text { weight } \\
\text { (g) }\end{array}$ \\
\hline & \multicolumn{10}{|c|}{ Summer season during 2014} \\
\hline TW & $6.00 \mathrm{e}$ & $87.67 f$ & $1.99 \mathrm{~d}$ & $1.32 \mathrm{~cd}$ & $0.40 \mathrm{c}$ & $4.2 \mathrm{~d}$ & $11.6 \mathrm{c}$ & $6.67 \mathrm{~d}$ & $0.187 f$ & $0.25 \mathrm{f}$ \\
\hline $15 \%$ PTW & $9.33 \mathrm{a}$ & $117.33 \mathrm{ab}$ & $2.81 \mathrm{ab}$ & $1.98 \mathrm{a}$ & $0.633 b$ & $5.0 \mathrm{~b}$ & $13.3 \mathrm{~b}$ & $8.51 \mathrm{c}$ & $0.292 \mathrm{c}$ & $0.89 b$ \\
\hline $25 \%$ PTW & $9.53 \mathrm{a}$ & $121.5 \mathrm{a}$ & $3.03 \mathrm{a}$ & $2.03 \mathrm{a}$ & $0.767 \mathrm{a}$ & $6.3 \mathrm{a}$ & $14.8 \mathrm{a}$ & $10.33 \mathrm{a}$ & $0.348 \mathrm{a}$ & $1.08 \mathrm{a}$ \\
\hline $15 \%$ GWW & $6.67 \mathrm{de}$ & $100.0 \mathrm{de}$ & $2.61 b$ & $1.16 \mathrm{de}$ & $0.307 \mathrm{c}$ & $3.57 \mathrm{e}$ & $11.5 \mathrm{c}$ & $4.57 f$ & $0.216 \mathrm{e}$ & $0.42 \mathrm{e}$ \\
\hline $25 \%$ GWW & $7.33 \mathrm{~cd}$ & $94.0 \mathrm{e}$ & $2.24 \mathrm{~cd}$ & $1.12 \mathrm{e}$ & $0.367 \mathrm{c}$ & $3.0 \mathrm{f}$ & $10.5 \mathrm{~d}$ & $4.33 \mathrm{f}$ & $0.279 \mathrm{c}$ & $0.70 \mathrm{c}$ \\
\hline 15\% Mix & $8.00 \mathrm{bc}$ & $105.83 \mathrm{~cd}$ & $2.51 \mathrm{bc}$ & $1.49 \mathrm{c}$ & $0.551 \mathrm{~b}$ & $4.3 \mathrm{~cd}$ & $13.0 \mathrm{~b}$ & $5.67 \mathrm{e}$ & $0.242 \mathrm{~d}$ & $0.35 \mathrm{ef}$ \\
\hline \multirow[t]{2}{*}{ 25\% Mix } & $8.67 \mathrm{ab}$ & $112.0 \mathrm{bc}$ & $2.76 \mathrm{~b}$ & $1.76 \mathrm{~b}$ & $0.600 \mathrm{~b}$ & $4.87 b c$ & $12.6 \mathrm{~b}$ & $9.53 b$ & $0.313 b$ & $0.55 \mathrm{~d}$ \\
\hline & \multicolumn{10}{|c|}{ Summer season during 2015} \\
\hline TW & $6.167 f$ & $95.33 d$ & $2.54 \mathrm{~d}$ & $1.29 \mathrm{~d}$ & $0.383 d$ & $4.503 c$ & $12.93 \mathrm{c}$ & $5.73 \mathrm{de}$ & $0.159 \mathrm{e}$ & $0.27 \mathrm{e}$ \\
\hline $15 \%$ PTW & $9.67 \mathrm{ab}$ & $116.67 \mathrm{ab}$ & $3.27 \mathrm{ab}$ & $1.95 \mathrm{ab}$ & $0.66 \mathrm{~b}$ & $5.16 \mathrm{~b}$ & $14.37 \mathrm{~b}$ & $9.16 \mathrm{~b}$ & $0.23 \mathrm{~cd}$ & $0.94 \mathrm{a}$ \\
\hline 25\% PTW & $9.87 \mathrm{a}$ & $124.0 \mathrm{a}$ & $3.55 \mathrm{a}$ & $2.0 \mathrm{a}$ & $0.775 \mathrm{a}$ & $5.392 \mathrm{a}$ & $15.07 \mathrm{a}$ & $10.83 a$ & $0.371 \mathrm{a}$ & $1.017 \mathrm{a}$ \\
\hline $15 \%$ GWW & $7.17 \mathrm{e}$ & $91.67 d$ & $2.395 \mathrm{de}$ & $1.18 \mathrm{~d}$ & $0.52 \mathrm{c}$ & $3.15 f$ & $12.2 \mathrm{~d}$ & $6.2 \mathrm{~cd}$ & $0.212 \mathrm{~d}$ & $0.59 \mathrm{c}$ \\
\hline $25 \%$ GWW & $7.83 d$ & $82.33 \mathrm{e}$ & $2.065 \mathrm{e}$ & $1.15 \mathrm{~d}$ & $0.407 \mathrm{~d}$ & $4.04 d$ & $11.1 \mathrm{e}$ & $5.03 \mathrm{e}$ & $0.26 \mathrm{c}$ & $0.73 b$ \\
\hline 15\% Mix & $8.47 \mathrm{c}$ & $106.17 \mathrm{c}$ & $2.895 \mathrm{c}$ & $1.53 \mathrm{c}$ & $0.617 \mathrm{~b}$ & $3.75 \mathrm{e}$ & $13.5 \mathrm{c}$ & $6.83 \mathrm{c}$ & $0.323 b$ & $0.38 \mathrm{~d}$ \\
\hline 25\% Mix & $9.13 b$ & $108.67 b c$ & $2.98 b c$ & $1.72 b c$ & $0.70 \mathrm{ab}$ & $4.45 \mathrm{c}$ & $13.8 \mathrm{bc}$ & $9.93 \mathrm{ab}$ & $0.309 \mathrm{~b}$ & $0.45 \mathrm{~d}$ \\
\hline
\end{tabular}


Table 3: The vegetative growth criteria and chemical analyses of Pistis stratuotus L. 'Water lettuce' grows under stress with using alternative sources of water [primary treated domestic wastewater and underground well water] during two summer seasons 2014 and 2015.

\begin{tabular}{|c|c|c|c|c|c|c|c|c|}
\hline Treatment & $\begin{array}{c}\text { Plants wet weight } \\
\text { at } 28^{\text {th }} \text { day } \\
\text { (g) }\end{array}$ & $\begin{array}{l}\text { Decrease of } \\
\text { biomass rate } \\
\text { (g/day) }\end{array}$ & $\begin{array}{l}\text { Decrease of } \\
\text { rosettes } \\
\text { diameter } \\
(\mathrm{cm}) \\
\end{array}$ & $\begin{array}{l}\text { W. weight of } \\
\text { frayed tissues }\end{array}$ & $\begin{array}{c}\text { Total chlorophyll } \\
\text { (mg/g) }\end{array}$ & $\mathbf{N \%}$ & $\mathbf{P \%}$ & $\mathbf{K} \%$ \\
\hline & \multicolumn{8}{|c|}{ Summer season during 2014} \\
\hline TW & $67.75 \mathrm{~d}$ & $-2.92 \mathrm{~cd}$ & $7.27 \mathrm{bc}$ & $55.33 \mathrm{~d}$ & $1.020 \mathrm{bcd}$ & 2.15 & 0.333 & 1.25 \\
\hline $15 \%$ PTW & $94.35 \mathrm{a}$ & $-3.45 b$ & $8.61 \mathrm{a}$ & $76.67 \mathrm{~b}$ & $1.147 \mathrm{~b}$ & 3.21 & 0.325 & 1.83 \\
\hline $25 \%$ PTW & $81.68 \mathrm{bc}$ & $-5.78 \mathrm{a}$ & $7.83 \mathrm{ab}$ & $89.33 \mathrm{a}$ & $1.82 \mathrm{a}$ & 3.32 & 0.416 & 1.98 \\
\hline $15 \%$ GWW & $87.95 \mathrm{ab}$ & $-2.11 f$ & $6.5 \mathrm{~cd}$ & 48.0de & 0.957 cde & 2.895 & 0.358 & 1.73 \\
\hline $25 \%$ GWW & $77.75 \mathrm{~cd}$ & $-2.36 \mathrm{ef}$ & $4.7 \mathrm{e}$ & $42.33 \mathrm{e}$ & $0.843 \mathrm{e}$ & 3.12 & 0.352 & 1.68 \\
\hline 15\% Mix & $87.76 \mathrm{abc}$ & $-2.71 \mathrm{de}$ & $6.2 \mathrm{~d}$ & $64.0 \mathrm{c}$ & $0.903 \mathrm{de}$ & 3.065 & 0.339 & 1.59 \\
\hline \multirow[t]{2}{*}{ 25\% Mix } & $90.24 \mathrm{ab}$ & $-3.18 b c$ & $5.77 \mathrm{~d}$ & $67.5 \mathrm{c}$ & $1.064 \mathrm{bc}$ & 3.06 & 0.411 & 1.64 \\
\hline & \multicolumn{8}{|c|}{ Summer season during 2015} \\
\hline TW & $79.75 \mathrm{c}$ & $-2.26 f$ & $7.07 \mathrm{c}$ & $59.213 d$ & $1.069 \mathrm{~cd}$ & 2.28 & 0.312 & 1.39 \\
\hline $15 \%$ PTW & $91.605 \mathrm{a}$ & $-3.67 b$ & $7.95 b$ & $74.243 b$ & $1.155 \mathrm{bc}$ & 3.17 & 0.421 & 1.96 \\
\hline $25 \%$ PTW & $89.75 \mathrm{ab}$ & $-4.98 \mathrm{a}$ & $8.94 \mathrm{a}$ & $88.656 \mathrm{a}$ & $1.894 \mathrm{a}$ & 3.19 & 0.424 & 2.01 \\
\hline $15 \%$ GWW & $68.33 d$ & $-3.36 b$ & $5.04 \mathrm{e}$ & $45.98 \mathrm{e}$ & $1.013 \mathrm{de}$ & 2.87 & 0.337 & 1.75 \\
\hline $25 \%$ GWW & $59.925 \mathrm{e}$ & $-3.23 c d$ & $6.73 c$ & $43.547 \mathrm{e}$ & $0.828 \mathrm{f}$ & 2.93 & 0.328 & 1.78 \\
\hline 15\% Mix & $86.08 b$ & $-2.85 \mathrm{de}$ & $6.55 \mathrm{c}$ & $64.767 \mathrm{c}$ & $0.921 \mathrm{ef}$ & 2.91 & 0.337 & 1.62 \\
\hline $25 \%$ Mix & $90.19 \mathrm{a}$ & $-2.63 \mathrm{ef}$ & $5.85 \mathrm{~d}$ & $68.523 c$ & $1.179 \mathrm{~b}$ & 3.05 & 0.354 & 1.82 \\
\hline
\end{tabular}


Table 4: The vegetative growth criteria and chemical analyses of Ceratophyllum demersum L."Hornwort" grows under stress with using alternative sources of water [primary treated domestic wastewater and underground well water] during two summer seasons 2014 and 2015.

\begin{tabular}{|c|c|c|c|c|c|c|c|c|c|c|c|}
\hline Treatments & $\begin{array}{c}\text { Shoots } \\
\text { fresh } \\
\text { weight }(g)\end{array}$ & $\begin{array}{c}\text { The growth } \\
\text { rate } \\
\text { (g/day) }\end{array}$ & $\begin{array}{l}\text { Shoots } \\
\text { dry } \\
\text { weight } \\
\text { (g) } \\
\end{array}$ & $\begin{array}{l}\text { Sediment w. } \\
\text { weight } \\
\text { (g) }\end{array}$ & $\begin{array}{c}\text { plants wet } \\
\text { weight at } \\
34^{\text {th }} \text { day } \\
\text { (g) }\end{array}$ & $\begin{array}{c}\text { Decrease of } \\
\text { biomass } \\
\text { rate } \\
\text { g/day } \\
\end{array}$ & $\begin{array}{l}\text { Wet weight } \\
\text { of frayed } \\
\text { tissues }\end{array}$ & $\begin{array}{c}\text { Total } \\
\text { chlorophyll } \\
(\mathrm{mg} / \mathrm{g})\end{array}$ & $\mathbf{N \%}$ & $\mathbf{P} \%$ & $\mathbf{K} \%$ \\
\hline \multicolumn{12}{|c|}{ Summer season during 2014} \\
\hline TW & $95.82 \mathrm{c}$ & $1.877 \mathrm{~b}$ & $1.29 \mathrm{a}$ & $0.621 \mathrm{~g}$ & $82.96 \mathrm{bc}$ & $-2.17 \mathrm{e}$ & $25.04 \mathrm{~d}$ & $5.517 \mathrm{c}$ & 1.81 & 0.586 & 1.60 \\
\hline 15\% PTW & $100.83 \mathrm{ab}$ & $2.025 \mathrm{ab}$ & $1.05 \mathrm{de}$ & $1.723 \mathrm{~b}$ & $86.39 a$ & $-2.35 \mathrm{de}$ & $26.72 b c$ & $5.944 \mathrm{a}$ & 2.64 & 0.701 & 2.03 \\
\hline 25\% PTW & $103.65 \mathrm{a}$ & $2.107 \mathrm{a}$ & $1.031 \mathrm{e}$ & $1.968 \mathrm{a}$ & $83.92 \mathrm{abc}$ & $-3.38 \mathrm{a}$ & $32.85 \mathrm{a}$ & $6.043 \mathrm{a}$ & 3.05 & 0.744 & 2.12 \\
\hline $15 \%$ GWW & $88.62 \mathrm{de}$ & $1.665 \mathrm{c}$ & $1.215 \mathrm{ab}$ & $0.787 \mathrm{f}$ & $72.17 \mathrm{~d}$ & $-2.65 \mathrm{~cd}$ & $27.63 \mathrm{bc}$ & $5.087 \mathrm{~d}$ & 1.92 & 0.594 & 1.62 \\
\hline $25 \%$ GWW & $86.94 \mathrm{e}$ & $1.620 \mathrm{c}$ & $1.25 \mathrm{ab}$ & $1.014 \mathrm{e}$ & $70.39 d$ & $-2.73 c$ & $26.09 \mathrm{~cd}$ & $5.099 \mathrm{~d}$ & 2.16 & 0.641 & 1.79 \\
\hline 15\% Mix & $97.07 \mathrm{bc}$ & $1.914 \mathrm{~b}$ & $1.12 \mathrm{~cd}$ & $1.163 \mathrm{~d}$ & $85.48 \mathrm{ab}$ & $-2.095 \mathrm{e}$ & $28.08 \mathrm{~b}$ & $5.604 \mathrm{c}$ & 1.98 & 0.609 & 1.68 \\
\hline 25\% Mix & $99.26 \mathrm{abc}$ & $1.978 \mathrm{ab}$ & $1.18 \mathrm{~b}$ & $1.306 \mathrm{c}$ & $81.37 \mathrm{c}$ & $-3.085 b$ & $31.44 \mathrm{a}$ & $5.752 \mathrm{~b}$ & 2.49 & 0.638 & 1.95 \\
\hline & \multicolumn{11}{|c|}{ Summer season during 2015} \\
\hline TW & $93.66 \mathrm{~d}$ & $1.643 \mathrm{~d}$ & $1.32 \mathrm{a}$ & $0.652 \mathrm{~d}$ & $74.39 \mathrm{~d}$ & $-3.24 c$ & $22.35 f$ & $5.59 \mathrm{~cd}$ & 2.04 & 0.614 & 1.70 \\
\hline $15 \%$ PTW & $104.53 \mathrm{ab}$ & $2.073 \mathrm{ab}$ & $1.075 \mathrm{~d}$ & $1.751 \mathrm{a}$ & $83.75 \mathrm{bc}$ & $-3.835 b$ & $30.46 \mathrm{c}$ & $5.97 \mathrm{ab}$ & 2.86 & 0.756 & 2.14 \\
\hline $25 \%$ PTW & $106.82 \mathrm{a}$ & $2.158 \mathrm{a}$ & $1.081 \mathrm{~d}$ & $1.954 \mathrm{a}$ & $80.76 \mathrm{c}$ & $-4.28 \mathrm{a}$ & $39.57 \mathrm{a}$ & $6.141 \mathrm{a}$ & 3.21 & 0.784 & 2.19 \\
\hline $15 \%$ GWW & $96.49 \mathrm{~d}$ & $1.753 \mathrm{~d}$ & $1.265 \mathrm{ab}$ & $0.755 \mathrm{~d}$ & $73.52 \mathrm{~d}$ & $-3.71 b$ & $28.53 \mathrm{~cd}$ & $5.124 \mathrm{e}$ & 2.49 & 0.652 & 1.75 \\
\hline $25 \%$ GWW & $100.95 \mathrm{bc}$ & $1.926 \mathrm{c}$ & $1.275 \mathrm{ab}$ & $1.023 \mathrm{c}$ & $92.89 \mathrm{a}$ & $-1.37 \mathrm{e}$ & $26.36 \mathrm{de}$ & $5.092 \mathrm{e}$ & 2.58 & 0.698 & 1.94 \\
\hline 15\% Mix & $100.67 \mathrm{c}$ & $1.94 \mathrm{bc}$ & $1.165 \mathrm{c}$ & $1.064 \mathrm{bc}$ & $83.08 \mathrm{c}$ & $-2.955 \mathrm{~cd}$ & $25.85 \mathrm{e}$ & $5.55 \mathrm{~d}$ & 2.76 & 0.633 & 1.88 \\
\hline 25\% Mix & $102.38 \mathrm{bc}$ & $2.013 \mathrm{abc}$ & $1.23 \mathrm{bc}$ & $1.268 \mathrm{~b}$ & $86.64 \mathrm{~b}$ & $-2.635 d$ & $36.15 b$ & $5.78 \mathrm{bc}$ & 2.94 & 0.706 & 2.06 \\
\hline
\end{tabular}


values of wet weight of frayed tissues resulted from $C$. demersum $\mathrm{L}$. draw attention to the fact that it is less than what is found in P. stratuotus L.

All these results are in harmony with those of Ghobrial, (2000); Patel and Kanungo, (2010); Foroughi et al., (2010) and Al-Ubaidy and Rasheed, (2015).

\section{3- Chemical constituents:}

Data of the effect of using alternative sources of water [primary treated domestic wastewater and underground well water and mix of them] on chemical constituents of Ceratophyllum demersum L."Hornwort" and Pistis stratuotus L. 'Water lettuce' are presented in Table (3, 4 and 5). The results cleared that there were significant differences between all treatments. The highest chlorophyll value was achieved from the treatment of $25 \% \mathrm{PTW}$ in P. stratuotus $\mathrm{L}$. and $25 \% \mathrm{PTW}$ and $15 \% \mathrm{PTW}$ in $C$. demersum L. plant in both seasons respectively, but the highest assimilation of total chlorophyll was increasing in $C$. demersum $\mathrm{L}$. shoots than $P$. stratuotus $\mathrm{L}$.

While, the highest values of N\% in Pistis stratuotus L. shoots were resulted from 25\% PTW and $25 \% \mathrm{PTW}$ and $15 \% \mathrm{PTW}$ in both seasons respectively, meanwhile the highest values of $\mathrm{P} \%$ were due to $25 \% \mathrm{PTW}$ and $25 \%$ Mix in $1^{\text {st }}$ season and $25 \% \mathrm{PTW}$ and $15 \% \mathrm{PTW}$ in $2^{\text {nd }}$ season. In the same trend the plants were treated by $25 \% \mathrm{PTW}$ were the highest in accumulation of $\mathrm{K} \%$.

Also, the superiority treatment in N\% in C. demersum L. shoots was $25 \% \mathrm{PTW}$ during two seasons. While, the highest values of $\mathrm{P} \%$ and $\mathrm{K} \%$ resulted from the treatments of $25 \% \mathrm{PTW}$ and $15 \% \mathrm{PTW}$ in $1^{\text {st }}$ season and $25 \% \mathrm{PTW}, 15 \% \mathrm{PTW}$ and $25 \%$ Mix in $2^{\text {nd }}$ season.

However, it was still the plants growing in the $25 \% \mathrm{PTW}$ treatment that achieved the highest values of nutrient assimilation. The observed results noted that $C$. demersum $\mathrm{L}$. was more concentrated in total chlorophyll and $\mathrm{P} \%$ analysis than P. stratuotus $\mathrm{L}$. plant. While the analyses of $\mathrm{N} \%$ and $\mathrm{K} \%$ were noted that there were similar accumulations among P. stratuotus $\mathrm{L}$. and $C$. demersum $\mathrm{L}$. in them tissues.

Similar findings were obtained by Brix, (1997); Lu et al., (2010); Patel and Kanungo, (2010); Galal \& Farahat (2015); Al-Ubaidy and Rasheed, (2015); Eid, (2017); Sidek et al. (2018) and Ali et al., (2020).

Moreover, because the treatment of $25 \% \mathrm{PTW}$ achieved the highest results in both plants, so it is appear in Table (5) the analyses of $\mathrm{Na}, \mathrm{Cd}$ and $\mathrm{Pb}$ in each plant tissues at $21^{\text {st }}$ day and $28^{\text {th }}$ day for Pistis stratuotus $\mathrm{L}$. and $28^{\text {th }}$ day and $34^{\text {th }}$ day for Ceratophyllum demersum L. during two seasons and water quality tests [color and turbidity] of the same treatment at before ( $1{ }^{\text {st }}$ day), during (at $21^{\text {st }}, 28^{\text {th }}$ day of the majority biomass for each plants) and after the experiment [at the day of $28^{\text {th }}$ and $34^{\text {th }}$ ] for each plants respectively.

The results noted that the day of $21^{\text {st }}$ and $28^{\text {th }}$ for each plant respectively ware achieved the highest values of bioaccumulations or phytoremidiation for $\mathrm{Na}, \mathrm{Cd}$ and $\mathrm{Pb}$ after that at $28^{\text {th }}$ and $34^{\text {th }}$ day for $P$. stratuotus and $C$. demersum respectively the accumulation of metals were started to decries in both plants tissue, which confirms the return of their release in water again. Also, the results of the analyses showed that $C$. demersum plant was better than P. stratuotus in assimilation of these metals. Meanwhile, the high values of water quality tests were decreased with the majority of biomass plant and their efficiency of metals accumulation at $21^{\text {st }}$ and $28^{\text {th }}$ day for both plants. But after increased of tissues deterioration, the water purity decreased again. Also, the efficiency of $C$. demersum plant was the best than $P$. stratuotus for water purification.

These results are in harmony with those of Ghobrial, (2000); Patel and Kanungo, (2010); Farnese et al., (2014); Ahmad et al., (2016); Sidek et al., (2018) and Ali et al., (2020).

\section{Recommendation:}

1- The experiment has shown that Pistis stratuotus L. 'Water lettuce' and Ceratophyllum demersum L."Hornwort" has a high ability to phytoremediation of aquatic ecosystem from harmful pollutant elements. Hence, it can be used for aesthetic purpose in aquariums or an economic purpose in fish farms, as they purify the pond water. However, they must be removed at the maximum growth stage without delay. Otherwise, pollutants will return to be released from the worn out tissues to be released again into the water, changing its bio-physiochemical properties and harms other aquatic organisms, increasing sediment and disturbing the waters smoothness, causing an infection of the lake or the pond.

2- The efficiency of phytoaccumulation of elements in Ceratophyllum demersum L. "Hornwort" is higher than that of Pistis stratuotus L. 'Water lettuce' plant. While, the frayed tissue in the 'Water lettuce' was higher than "Hornwort" plant. 
Table 5: The metal concentration in dry weight of Pistis stratuotus L. 'Water lettuce' and Ceratophyllum demersum L. "Hornwort" and water quality tests in the treatment of 25\%PTW during two summer seasons 2014 and 2015.

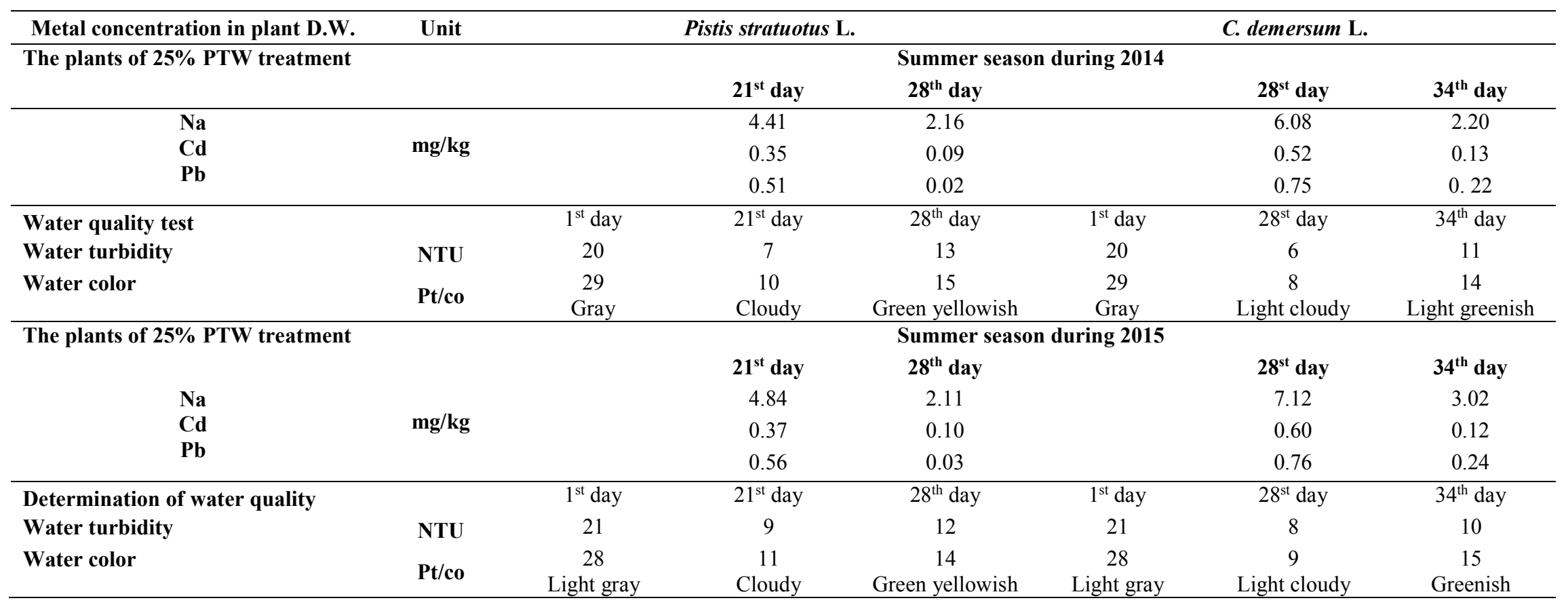


3- The water quality test indicated that the plants adsorbed the turbidity or secreted substances that turned them into sediment. So it can be recommended to study this phenomenon in the future. However, the water color turned green at the end of the experiment, possibly due to the frayed parts of the plant.

\section{Acknowledgements:}

Special thanks to the seniors, professors and assistants of the National Institute of Oceanography and Fisheries, the Chemistry Laboratory and the Marine Environment Division, El- Anfoushi, Qaitbay, Alexandria, Egypt and the Egyptian Water Bodies Police. This is due to their cooperation with the author in providing the Macrophytes samples under study, as well as all the necessary chemical analyzes.

\section{References}

Abu, T. 2017. A Review: Aquatic macrophyte Ceratophyllum demersum L. (Ceratophyllaceae): Plant Profile, Phytochemistry and Medicinal Properties. International Journal of Science and Research (IJSR), vol. 6, Issue 7, 394-399. DOI: 10.21275/ART20174667.

Ahmad, S.S., Z.A. Rashi, M.A. Shah, I. Rashid, R. Ara and S.M.A. Andrabi, 2016. Heavy metal accumulation in the leaves of Potamogeton natans and Ceratophyllum demersum in a Himalayan RAMSAR site: management implications. Wetlands Ecol Manage, 24: 469 - 475.

Akapo, A.A., S.O. Omidiji and A.A. Otitoloju, 2011. Morphological and anatomical effects of crude oil on Pistia stratiotes. Environmentalist. 31:288-298.

Ali, M. M. and M. E. Soltan, 1999. Heavy metals in aquatic Macrophytes, water and hydrosoils from the River Nile, Egypt. Journal of Union Arab Biologists, 9(B): 99-115.

Ali, M. M., V. SpringuelI and H.A. Yacoub, 1999. Submerged plants as bioindicators for aquatic habitat quality in the River Nile. Journal of Union Arab Biologists, 9(B): 403-418.

Ali, S., Z.,Abbas M. Rizwan, I.E. Zaheer, I. Yavas, A. Unay, M.M. Abdel-Daim, M. Bin-Jumah, M. Hasanuzzaman and D.Kalderis, 2020. Application of floating aquatic plants in phytoremdiation of heavy metals polluted water: A review. Sustainability, 12(1927):1-33; doi: $10.3390 /$ su12051927.

Al-Ubaidy, H.J. And K.A. Rasheed 2015. Phytoremdiation of Cadmium in river water by Ceratophyllum demersum. World Journal of Experimental Biosciences, 3(1): 14-17.

Barcelo, J., M.D. Vázquez and C. Poschenrieder, 1988. Structural and ultrastructural disorders in cadmium-treated bush bean plants (Phaseolus vulgaris L.). The New Phytologist, vol.108, no. 1, p. 37-49. http://dx.doi.org/10.1111/j.1469-8137.1988.tb00202.x.

Brix, H., 1997. Do macrophytes play a role in constructed treatment wetlands? Water Sci. Tech. 35(5): $11-17$

Brown, J. D. and O. C. Lilliland, 1946. Rapid determination of potassium and sodium in plant material and soil extracts by flame photometry. Proceedings of the American Society for Horticultural Science, 48: 341-346.

Cheung, C.W. Porter, C.F. McKay, 1997. Sorption kinetics for the removal of copper and zinc from effluents using bone char. Sep Purif Technol., 19:55-64.

Ding, W., X. He and W. Chen, 2011. "Runoff and Sediment Reduction by Riparian Buffer Filters on Steep Slopes;" proceedings of the International Conference on Computer Distributed Control and Intelligent Environmental Monitoring, Changsha, Hunan China, February 19-20, 2011.

Eid, E.M., T.M. Galal, M.A. Dakhil and L.M. Hassan, 2016. Modeling the growth dynamics of Pistia stratiotes L. populations along the water courses of south Nile Delta, Egypt. Rendiconti Lincei. 27:375-382.

Eid, E.M., 2017. Verification of a numerical growth model of Pistia stratiotes L. using field data from tropical and subtropical sites. Journal of Freshwater Ecology, 32(1): 391-403.

Evenhuis, B. and P.W. Deward, 1980. Principles and practices in plant analysis. FAO, Soil Bulleten., 38 (1): 152-162.

Farnese, F.S., J.A. Oliveira, G.S. Gusman, G.A. Leão, N.M. Silveira, P.M. Silva, C. Ribeiro and J. Cambraia 2014. Effects of adding nitroprusside on arsenic stressed response of Pistia stratiotes L. under hydroponic conditions. International Journal of Phytoremediation, vol. 16, no. 2, p. 123 137. http://dx.doi.org/10.1080/15226514.2012.759532. PMid:24912205 
Foroughi, Maryam, P. Najafi, A. Toghinani and N. Honarjoo, 2010. Analysis of pollution removal from wastewater by Ceratophyllum demersum. African Journal of Biotechnology, 9(14): 2125-2128.

Faroughi, Maryam, 2011. Role of Ceratophyllum demersum in recycling macro elements from wastewater. J. Appl. Sci. Environ. Manage., 15 (2):401 - 405.

$\mathrm{Fu}, \mathrm{X}$. and X. He, 2015. Nitrogen and phosphorus removal from contaminated water by five aquatic plants. International Conference on Mechatronics, Electronic, Industrial and Control Engineering (MEIC 2015): 1274- 1277.

Gabra, Georgena R.W., 2021. Response of Narcissus Constantinople 'Double Roman' plants of some natural and chemical fertilizers. Egypt. Acad. J. Biolog. Sci., 12(1):147- 160.

Galal, T.M. and Farahat E.A. 2015.The invasive macrophyte Pistia stratiotes L. as a bioindicator for water pollution in Lake Mariut, Egypt. Environ Monit Assess., 187:701-710.

Ghobrial, Mary G., 2000. Treatment of cadmium, copper zinc and iron in wastewater by the Hornwort Ceratophyllum demersum. Egypt. J. Aquat. Biol. \& Fish., 4(1):35-46.

Hanafiah, M. M.; Mohamad N. H. S. M. and Abd Aziz N. I. H. 2018. Salvinia molesta dan Pistia stratiotes sebagai agen fitoremediasi dalam rawatan air sisa kumbahan. Sains Malaysiana, 47: $1625-1634$.

Kumar V.K., J. Singh and P. Kumar, 2019. Phytoremediation of copper, iron and mercury from aqueous solution by water lettuce (Pistia stratiotes L.). Environmental Sustainability, 2: 55-65.

Kushwaha A., R. Rani, S. Kumar and A. Gautam 2015. Heavy metal detoxification and tolerance mechanisms in plants: Implications for phytoremediation. Environ. Rev., 23: 1-13.

Jia L., X. He, W. Chen, Z. Liu, Y. Huang and S. Yu, 2013. Hormesis phenomena under Cd stress in a hyperaccumulator Lonicera japonica Thund. Ecotoxicology, 22; 476-485.

Lu Q., Z.L. He, D. A. Graetz, P. J. Stoffella and X.Yang, 2010. Phytoremediation to remove nutrients and improve eutrophic storm waters using water lettuce (Pistia stratiotes L.). Environ. Sci. Pollut. Res., 17(1):84-96.

Mahr, Susan, 2012. Water Lettuce, Pistia stratiotes. University of Wisconsin - Madison A Horticulture Information article from the Wisconsin Master Gardener website, posted 30 April 2012.

Malathy, R. and S.A. Stanley, 2015. Studies on the potential therapeutic effects on the aquatic macrophytes namely Cabomba aquatica, Ceratophyllum demersum and Hygrophila corymbosa. Journal of Chemical and Pharmaceutical Research, 7(4):479-483.

Miretzky, P., A. Saralegui and A.F. Cirelli, 2004. Aquatic macrophytes potential for the simultaneous removal of heavy metals. Chemosphere, 57: 997-1005.

Mitsch,W.J. and S.E. Jorgensen, 1989. Ecological Engineering: An Introduction to Ecotechnology. John Wiley \& Sons, New York, pp.472.

Moran, R., 1982. Formula for determination of chlorophyllous pigment extracted with N. N dimethl formamide. Plant Physiology, 69:1376-1381.

Patel, D.K. and V.K. Kanungo, 2010. Ecological efficiency of Ceratophyllum demersum L. in phytoremediation of nutrients from domestic wastewater. The Ecoscan.,4(4):257-262.

Shaltout, K. H., T. M. Galal and M. El-Komi, Thanaa 2009. Evaluation of the nutrient status of some hydrophytes in the water courses of Nile delta, Egypt. Journal of Botany, 1-11. Article ID, 862565. doi: $10.1155 / 2009 / 862565$.

Sharma, P., A.B. Jha, R.S. Dubey and M. Pessarakli, 2012. Reactive oxygen species, oxidative damage, and antioxidative defense mechanism in plants under stressful conditions. Le Journal de Botanique, (2012): 1-26.

Sidek, N.M., S.R.S. Abdullah, N.U. Ahmad, S.F.S. Draman, M.M.M. Rosli and M.F. Sanusi, 2018. Phytoremediation of abandoned mining lake by water hyacinth and water lettuces in constructed wetlands. Journal of Technologic (Sciences \& Engineering), 80(5):87-93.

Smith, V.H., G.D. Tilman and J.C. Nekola 1999. "Eutrophication: impacts of excess nutrient inputs on freshwater, marine, and terrestrial ecosystem". Environment Pollution, 100:179-19.

Snedecor, G. and W. Cochran 1974. Statistical methods. Sixth Ed. Iowa State University Press, Ames, Iowa, USA.

Stebbing, A. R. D., 1981. Hormesis, the stimulation of growth by low level of inhibitors. The Science of the Total Environment. 22: 213-234

Sternberg, S.P.K. And R.W. Dom, 2002. Cadmium removal using Cladophora in batch, semi-batch and flow reactors. Bioresour Technol., 81:249-255. 
Thijs S., W. Sillen, N. Weyens and J. Vangronsveld, 2017. Phytoremediation: State of-the-art and a key role for the plant microbiome in future trends and research prospects. Int. J. Phytoremediation 19:23-38.

Trouge, E. and A. H. Meyer, 1939. Improvement in denies calorimetric for phosphorus and arsenic. Ind. Eng. Chem. Anal. Ed., 1: 136-139.

Valipour, A., N. Hamnabard, K.S. Woo and Y.H. Ahn, 2014. Performance of high-rate constructed phytoremediation process with attached growth for domestic wastewater treatment: Eject of high TDS and Cu. Journal of Environmental Management, 145: 108.

Victor, K.K., Y. Séka, K. K. Norbert, T.A. Sanogo and A.B. Celestin 2016. Phytoremediation of wastewater toxicity using water hyacinth (Eichhorina crassipes) and water lettuce (Pistia stratiotes). International Journal of Phytoremediation, 18(10): 949- 955.

Volesky, B. 2003. Sorption and Biosorption, BV Sorbex, Inc., St. Lambert, Quebec.

Yadav, S.K., A.A. Juwarkar, G.P. Kumar, P.R. Thawale, S.K. Singh and T. Chakrabarti, 2009. Bioaccumulation and phytotranslocation of $\mathrm{Ar}, \mathrm{Cr}$ and $\mathrm{Zn}$ by Jatropha curcas L.: Impact of dairy sludge and biofrtilizer. Bioresource Technology, 100:4646-4622

Yang, X., S. Chen and R. Zhang 2014. Utilization of two invasive free-floating aquatic plants (Pistia stratiotes and Eichhornia crassipes) as sorbents for oil removal. Environ. Sci. Pollut. Res., 21:781-786. 